\title{
Influence of nitrogen and potassium on tomato nutrition and resistance to Liriomyza sativae (Diptera: Agromyzidae) in greenhouse
}

\author{
Carlos Magno Ramos Oliveira ${ }^{1 *} \mathbb{\oplus}$, Renato Ribeiro Passos ${ }^{1} \oplus$, Dirceu Pratissoli ${ }^{1} \mathbb{0}$, \\ Anderson Mathias Holtz ${ }^{2}$, Otacílio José Passos Rangel ${ }^{3}[$

\footnotetext{
${ }^{2}$ Instituto Federal de Educação, Ciência e Tecnologia do Espírito Santo, Campus Itapina, Colatina, ES, Brasil. E-mail: anderson.holtz@ifes.edu.br

${ }^{3}$ Instituto Federal de Educação, Ciência e Tecnologia do Espírito Santo, Campus Alegre, Alegre, ES, Brasil. E-mail: ojprangel@ifes.edu.br
} \\ 1 Universidade Federal de Alegre, Alegre, ES, Brasil. E-mail: carlosmagnoramos@yahoo.com.br; renatoribeiropassos@hotmail.com; dirceu.pratissoli@gmail.com
}

ABSTRACT: The influence of different nitrogen and potassium ratios on mineral nutrition and resistance of tomato plants to leafminer fly attack was evaluated. Tomato variety Alambra F1 was grown to conduct the experiment in a randomized block design, with 4 repetitions, in a $5 \times 5$ factorial scheme, being 5 doses of nitrogen and 5 doses of potassium at levels $0,50,100$, 150 , and $200 \%$ for each nutrient and in a $5 \times 5$ factorial design, being $0,0.5,1,1.5$, and 2 for each ratio between nitrogen and potassium $(\mathrm{N} / \mathrm{K})$ in the analyses on the leafminer fly. For infestation, the $3^{\text {rd }}$ or $4^{\text {th }}$ leaf was selected and covered with a Voile-type cloth bag with 10 leaf fly adults for 24 hours. The confinement test took place on the $3^{\text {rd }}$ or $4^{\text {th }}$ leaf, where nitrogen and potassium contents, larval and pupal duration and viability, longevity and sex ratio of the adults were also analyzed. The tomato plants showed increasing levels of nitrogen and potassium as their respective levels increased in the combinations studied. The N/K $1 / 1$ ratio showed unfavorable averages for the insect as egg viability and/or larval development of Liriomyza sativae, indicating a possible induced resistance of the tomato plants to the leafminer fly.

\section{Influência do nitrogênio e potássio na nutrição do tomateiro e em sua resistência a Liriomyza sativae (Diptera: Agromyzidae) em casa de vegetação}

RESUMO: Avaliou-se a influência de diferentes relações entre nitrogênio e potássio sobre a nutrição mineral e resistência do tomateiro ao ataque de mosca-minadora. Cultivou-se o tomate variedade Alambra F1 para se conduzir o experimento em delineamento em blocos casualizados, com 4 repetições, num esquema fatorial $5 \times 5$, sendo 5 doses de Nitrogênio e 5 doses de Potássio nos níveis $0,50,100,150$ e $200 \%$ para cada nutriente e num desenho fatorial $5 \times 5$, sendo $0,0,5,1,1,5$ e 2 para cada relação entre Nitrogênio e Potássio (N/K) nas análises sobre a mosca-minadora. Para infestação, selecionou-se a $3^{a}$ ou $4^{\text {a }}$ folha que então foram cobertas por uma sacola de tecido tipo Voal com 10 adultos de mosca-minadora por 24 horas. $O$ teste de confinamento se deu na $3^{\mathrm{a}}$ ou $4^{\mathrm{a}}$ folha, onde também se analisou os teores de nitrogênio e potássio, duração e viabilidade larval e pupal, longevidade e razão sexual dos adultos. 0 tomateiro apresentou teores crescentes de nitrogênio e potássio à medida que se aumentou seus respectivos níveis nas combinações estudadas. A relação N/K $1 / 1$ apresentou médias desfavoráveis ao inseto como viabilidade dos ovos e/ou desenvolvimento das larvas de Liriomyza sativae, indicando uma possível resistência induzida do tomateiro à mosca-minadora.

Palavras-chave: fertilidade; adubação; manejo de pragas; tomate

\footnotetext{
${ }^{*}$ Carlos Magno Ramos Oliveira - E-mail: carlosmagnoramos@yahoo.com.br (Corresponding author)

Associate Editor: Elton Lúcio de Araújo
} 


\section{Introduction}

Tomato (Solanum lycopersicum (L.) H. Karst.) is one of the most widely planted vegetable crops in Brazil (Cepea, 2019/2020). In all producing states, the intensive management of the crop stands out, with the application of pesticides to control pests and diseases, as well as the use of chemical fertilizers, especially the macronutrients nitrogen, phosphorus, and potassium (Oliveira, 2014). Among the pests of relevance to tomato, the leafminer fly Liriomyza sativae Blanchard (Diptera: Agromyzidae) is of nationwide importance due to how quickly it acquires resistance to insecticides registered for the crop (Costa-Lima et al., 2019).

In tomato, potassium is taken up in larger amounts when compared to other nutrients, and together with nitrogen, which has a prominent role in protein production, contribute directly to fruit yield and quality (Felix et al., 2015) and also has a prominent role as an enzyme activator (Butzke, 2019). In turn, the unbalanced supply of these nutrients to tomato plants favors, to some degree, that their tissues become food for phytophagous insects (Becker et al., 2016). Under these conditions, the leafminer fly feeds on the leaves of the tomato plant, reducing its photosynthetic capacity, affecting the entire plant. Thus, as a consequence of this attack, the severely attacked leaves dry out and fall, exposing the fruit to solar radiation, decreasing its commercial viability, thus affecting the quality of its production (Oliveira, 2014).

Francis Chaboussou was a pioneer in correlating the susceptibility of plants to pest attack due to nutritional imbalance in the soil, proposing based on the conclusions of his studies the trophobiosis theory (Santos \& Silva, 2020). From his analyses, some studies have been conducted evaluating the effects of fertilization on the occurrence of pests. However, despite the great relevance of the theme, the difficulty in establishing an interdisciplinary research group, a fact present in most works, hinders the prevalence of this type of study.

Therefore, this work aims to evaluate the effects of different nitrogen and potassium ratios on mineral nutrition and resistance of tomato plants to attack by leafminer fly $L$. sativae under greenhouse conditions.

\section{Materials and Methods}

\section{Experiment setup}

The experiment was conducted in the greenhouse of the Center for Scientific and Technological Development in
Phytosanitary Management of Pests and Diseases (NUDEMAFI), located in the Center for Agricultural Sciences of the Federal University of Espírito Santo (CCA-UFES), 20 $45^{\prime} 48^{\prime \prime} \mathrm{S}$ latitude and $41^{\circ} 31^{\prime} 57^{\prime \prime} \mathrm{W}$ longitude, at an altitude of $150 \mathrm{~m}$ in Alegre, ES, Brazil. According to Incaper (2020), the predominant climate is hot and humid in summer and dry winter, average annual rainfall of $1,200 \mathrm{~mm}$ and average annual temperature of 22.2 ${ }^{\circ} \mathrm{C}$, with daily highs of $29^{\circ} \mathrm{C}$ and lows of $16.9^{\circ} \mathrm{C}$.

The soil used is a dystrophic Red-Yellow Latosol, medium texture, collected at a depth of $0-20 \mathrm{~cm}$, which after being collected it was air-dried, crushed, and passed through a $2.0 \mathrm{~mm}$ sieve to obtain fine air-dried soil (FADS). After that, it was chemically and physically characterized using the methodology described by Teixeira et al. (2017).

To correct soil acidity, magnesian limestone was used, properly homogenized, applied to samples with a volume of $1.7 \mathrm{dm}^{3}$ of FADS, seeking to reach $80 \%$ base saturation, according to Prezotti et al. (2007) by means of incubation (Freire et al., 1980). The moisture content of the pots was raised until it reached $60 \%$ of the total pore volume.

Tomato seeds of the Alambra F1 variety were sown and after reaching a height of $10.0 \mathrm{~cm}$ one seedling per pot of 2.0 $\mathrm{dm}^{3}$ was transplanted. When they reached the height of 30.0 $\mathrm{cm}$ the plants were staked. The average final weight of the pots was $2.37 \mathrm{~kg}$.

Fertilization with nitrogen and potassium was done with ammonium sulfate P.A., calcium phosphate P.A. and monobasic potassium chloride P.A. via irrigation water. For this, we used morning and afternoon weighing of the pots, replacing the weight lost during the day through two irrigations as proposed by Novais et al. (1991). Weed control was done manually. The experimental period was 45 days, from transplanting to pupae collection.

\section{Evaluation of nutritional parameters}

To evaluate the influence of different doses of nitrogen and potassium on the nutritional parameters, related to nitrogen and potassium leaf levels of tomato plants, a randomized block design was used for the experiment, distributed in a $5 \times$ 5 factorial scheme, with 4 repetitions (Table 1 ).

Phosphorus was applied in a single plot and its amount was the same for all treatments, corresponding to $300 \mathrm{mg} \mathrm{kg}^{-1}$. At the same time, half of the nitrogen and potassium doses, applied moments before transplanting the tomato plants, were placed. Fifteen days after transplanting, the other half of the $\mathrm{N}$ and $\mathrm{K}$ doses were applied via irrigation water.

Table 1. Relationships and levels of nitrogen and potassium based on the adequate content for tomato proposed by Prezotti et al. (2007).

\begin{tabular}{|c|c|c|c|c|c|c|c|c|c|}
\hline N/K ratio & $\begin{array}{l}\text { Level of N/K } \\
(\%)\end{array}$ & N/K ratio & $\begin{array}{l}\text { Level of } \mathrm{N} / \mathrm{K} \\
(\%)\end{array}$ & N/K ratio & $\begin{array}{l}\text { Level of } \mathrm{N} / \mathrm{K} \\
(\%)\end{array}$ & N/K ratio & $\begin{array}{l}\text { Level of } \mathrm{N} / \mathrm{K} \\
\text { (\%) }\end{array}$ & $\mathrm{N} / \mathrm{K}$ ratio & $\begin{array}{l}\text { Level of } \mathrm{N} / \mathrm{K} \\
(\%)\end{array}$ \\
\hline $0 / 0$ & $0 / 0$ & $0.5 / 0$ & $50 / 0$ & $1 / 0$ & $100 / 0$ & $1.5 / 0$ & $150 / 0$ & $2 / 0$ & $200 / 0$ \\
\hline $0 / 0.5$ & $0 / 50$ & $0.5 / 0.5$ & $50 / 50$ & $1 / 0.5$ & $100 / 50$ & $1.5 / 0.5$ & $150 / 50$ & $2 / 0.5$ & $200 / 50$ \\
\hline $0 / 1$ & $0 / 100$ & $0.5 / 1$ & $50 / 100$ & $1 / 1$ & $100 / 100$ & $1.5 / 1$ & $150 / 100$ & $2 / 1$ & $200 / 100$ \\
\hline $0 / 1.5$ & $0 / 150$ & $0.5 / 1.5$ & $50 / 150$ & $1 / 1.5$ & $100 / 150$ & $1.5 / 1.5$ & $150 / 150$ & $2 / 1.5$ & $200 / 150$ \\
\hline $0 / 2$ & $0 / 200$ & $0.5 / 2$ & $50 / 200$ & $1 / 2$ & $100 / 200$ & $1.5 / 2$ & $250 / 200$ & $2 / 2$ & $200 / 200$ \\
\hline
\end{tabular}


At 45 days after transplanting, the $3^{\text {rd }}$ or $4^{\text {th }}$ leaf of the tomato plant was cut, where the leafminer fly adults were confined. The leaves were placed in properly identified paper bags and taken to a forced air circulation oven at a temperature of $65^{\circ} \mathrm{C}$ for 72 hours. The dried material was ground in a Wiley mill, equipped with a stainless steel sieve with $0.42 \mathrm{~mm}$ mesh, and packed in paper bags properly identified for chemical analyses of the macronutrient contents of nitrogen $(N)$ and potassium (K).

\section{Evaluation of entomological parameters}

For the analysis of entomological parameters related to the leafminer fly, the experiment was conducted in a randomized block design with 25 treatments [ratios of the adequate dose of nitrogen/potassium (g/vase)] in each block, with 4 repetitions, as proposed in the nutrient parameter analysis.

To obtain the adults of $L$. sativae used in the experiment, we resorted to stock breeding at the Center for Scientific and Technological Development in Phytosanitary Management of Pests and Diseases (NUDEMAFI), which uses a breeding methodology adapted from Costa-Lima et al. (2017).

To evaluate the resistance of tomato plants to the leafminer fly under different $\mathrm{N} / \mathrm{K}$ ratios, a confinement test was conducted on 40-day transplanted tomato plants. For infestation, a leaf was selected from the plants found in the area indicated as pest attack, located in the upper third ( $3^{\text {rd }}$ or $4^{\text {th }}$ leaf from the apex of the plant) (Fornazier et al., 2010). After the leaf was selected, it was wrapped with a 22 $\mathrm{cm}$ long by $15 \mathrm{~cm}$ wide voile type fabric, which constituted a bag. Subsequently, ten 24-hour-old leafminer fly adults were aspirated from Petri dishes used for stock brood maintenance into $1.5 \mathrm{~cm}$ diameter by $2.5 \mathrm{~cm}$ high acrylic tubes, which were then sealed with plastic film. These acrylic tubes were inserted from the base of each voile bag, the plastic film removed, and then the voile was attached to the leaf sheath using crepe tape. Adults of $L$. sativae were confined for 24 hours to enable crossing and oviposition on the leaflet.

After this period, the bags with the insects were removed from the leaves, which were properly identified. The infested plants were kept in the greenhouse and monitored daily during the egg and early larval stages with the aid of a pocket magnifier at 30x magnification. From the observation of larval development, the bags were placed back on the leaves and remained until the pre-pupa emerged while still in the mobile stage, when the leaves were then removed. The pupae from each repetition were counted and separated individually in minigerbox-type plates $(2.5 \mathrm{~cm}$ diameter and $1.5 \mathrm{~cm}$ high), lined with filter paper and placed in an air-conditioned chamber (B.O.D.) with a 12 hour photoperiod and a 28 oc daily temperature and humidity of $50 \%$.

Entomological variables analyzed in the Entomology Laboratory of NUDEMAFI and consisted of larval and pupal duration and viability, longevity and sex ratio of adults. To measure the larval stage, the leaves on which they were subjected to confinement were observed, identifying the punctures, and following their development using a magnifying glass at 30x magnification. After hatching, the duration of the larval period was counted until the pre-pupa emerged. The pupal duration was measured by counting the days from the exit of the pre-pupa from the leaf to the emergence of the adult. The sex ratio was calculated using the formula: $r s=$ no. of females/no. of females + no. of males.

\section{Statistical analysis}

Data were subjected to analysis of variance using SISVAR software (Ferreira, 2019) and when significant for the quantitative factors (nitrogen and potassium contents found in the $3^{\text {rd }}$ or $4^{\text {th }}$ leaf), response surface was used in the presentation of graphs for the pair. The models were chosen based on the significance of the response surface coefficients, using Student t-test at 5\% probability, and by the coefficient of determination $\left(R^{2}\right)$. For the significant qualitative factors related to entomological variables (larval viability, pupal viability, duration of larval and pupal stages, sex ratio, and longevity), the Scott-Knott test ( $p \leq 0.05)$ was used to compare the treatments.

\section{Results and Discussion}

\section{Nutritional parameters}

The interaction between nitrogen and potassium levels proved to be significant $(\mathrm{p}<0.05)$ for the $\mathrm{N}$ contents of the $3^{\text {rd }}$ or $4^{\text {th }}$ leaf of the tomato plant with fitting of the results to the polynomial model (Figure 1). An increase in $\mathrm{N}$ contents was observed on the response surface as an increase in the combinations of nitrogen and potassium was obtained up to the highest level studied for both nutrients. In the combination of the lowest levels of nitrogen and potassium applied $(0 \%$, respectively) the lowest average nitrogen content $\left(7.87 \mathrm{~g} \mathrm{~kg}^{-1}\right)$ was obtained. In the other combinations, an increase in $\mathrm{N}$ contents was observed, with the highest average nitrogen content $(19.68$ $\mathrm{g} \mathrm{kg}^{-1}$ ) obtained in the combination of $200 \%$ nitrogen and $200 \%$

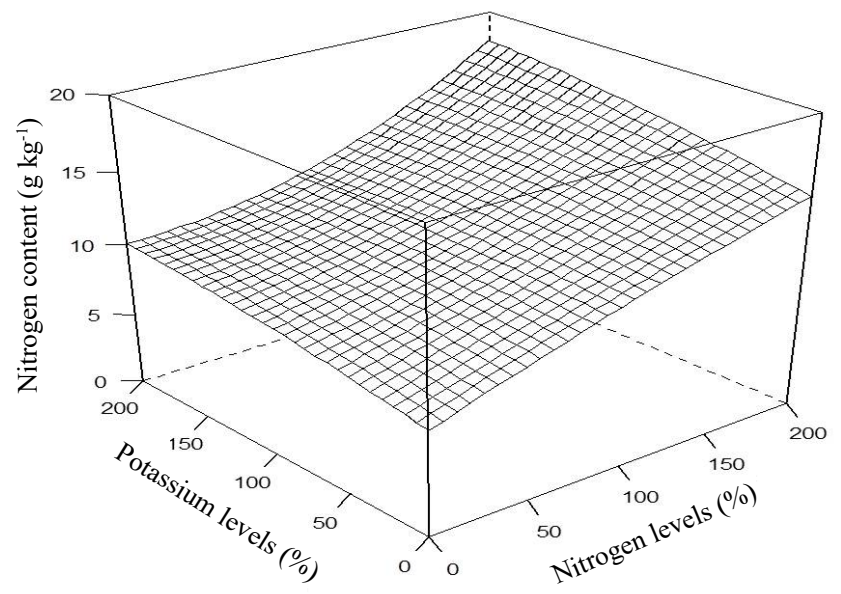

$$
R^{2}=0.76
$$

$\hat{Y}=7.250+4.411^{* * *} R N+0.004^{* * *} R K-0.00003^{* *} R N^{2}-0.002^{* *} R N x R K+0.000001^{*} R K x R N^{2}$ *** significant at $1 \%$; * significant at $10 \%$; significant at $5 \%$;

Figure 1. Nitrogen contents $\left(\mathrm{g} \mathrm{kg}^{-1}\right)$ of the $3^{\text {rd }}$ or $4^{\text {th }}$ leaf of tomato (Solanum lycopersicon), as a function of applied potassium and nitrogen levels. 
potassium (Figure 1). The combinations between $200 \% \mathrm{~K}$ with 0,50 , and $100 \% \mathrm{~N}$ showed the slowest growth rate for nitrogen content among all the ratios (Figure 1).

$\mathrm{K}$ is an important agent in the metabolism of nitrogen compounds (Butzke, 2019). The increased $\mathrm{N}$ content resulting from the combinations of nitrogen and potassium may have occurred as a consequence of the increased levels of $\mathrm{K}$ in the soil, a fact that may have favored increased $\mathrm{N}$ uptake in the form of ammonium $\left(\mathrm{NH}_{4}^{+}\right)$. Nitrogen uptake can be stimulated by potassium supply (Pinto \& Araújo, 2019), so knowledge of the relationship of potassium on nitrogen is necessary. Silva et al. (2016) stated that when potassium fertilization is insufficient, this can cause increased $\mathrm{NH}_{4}^{+}$adsorption by the soil, negatively influencing $\mathrm{N}$ availability to plants. These findings are due to the fact that $\mathrm{K}^{+}$competes with $\mathrm{NH}_{4}^{+}$for soil exchange complex sites, and higher levels of potassium in the soil would leave more $\mathrm{NH}_{4}^{+}$free in solution for uptake by the tomato plant. Another fact that may also have contributed to the influence of potassium levels on nitrogen contents was that the amount of nitrogen found in the leaf dry mass $\left(\mathrm{g} \mathrm{kg}^{-1}\right)$ was lower than the amount of $\mathrm{K}$ in the leaf dry mass $\left(\mathrm{g} \mathrm{kg}^{-1}\right)$, indicating that, proportionally, there was a greater uptake of potassium and this may have resulted in a greater influence of this nutrient on nitrogen.

The potassium contents of the $3^{\text {rd }}$ or $4^{\text {th }}$ leaf of the tomato plant showed significant quadratic fits $(p<0.05)$ for the interaction between nitrogen and potassium levels (Figure 2). The lowest average $\mathrm{K}$ contents $\left(18.89 \mathrm{~g} \mathrm{~kg}^{-1}\right)$ were found at the $0 \%$ potassium level combined with all $\mathrm{N}$ levels (Figure 2 ). The highest average value was obtained at the $200 \% \mathrm{~K}$ and $50 \%$ $\mathrm{N}$ dose, corresponding to $37.58 \mathrm{~g} \mathrm{~kg}^{-1}$. As the levels of $\mathrm{K}$ were increased from $0 \%$ to $200 \%$, regardless of the combination that was established with $\mathrm{N}$, an increase in the average potassium content was observed (Figure 2), indicating that this nutrient was not affected by nitrogen in terms of its uptake, perhaps

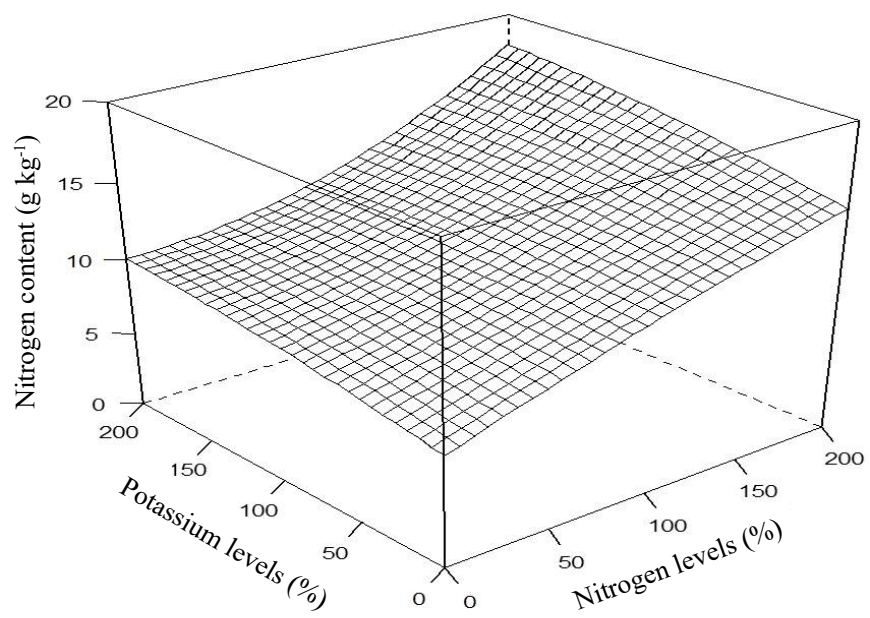

$R^{2}=0.94$

$\hat{Y}=2.608+0.2831^{* *} R K-0.00058^{* *} R K^{2}-0.0000004^{* *} R K x R N^{2}$

** significant at $10 \%$

Figure 2. Potassium contents $\left(\mathrm{g} \mathrm{kg}^{-1}\right)$ of the $3^{\text {rd }}$ or $4^{\text {th }}$ leaf of tomato (Solanum lycopersicon), as a function of applied potassium and nitrogen levels. due to the fact that, proportionally, potassium was taken up in greater quantity than nitrogen, and was therefore not influenced by this nutrient. In the combination between the $200 \% \mathrm{~K}$ doses and the different nitrogen levels, it was noted that there was an increase in the average potassium contents between 0,50 and $100 \mathrm{~N}$, decreasing at 150 and $200 \mathrm{~N}$, being $30.76,37.01,37.58,32.68$, and 28.69, respectively (Figure 2).

This result evidenced that there was no influence of the nitrogen source on the potassium contents, which allowed the plants to absorb and allocate $\mathrm{K}$ contents in the leaves under confinement as a function of the applied levels. The interaction between $\mathrm{K}$ and $\mathrm{N}$ is usually of the non-competitive type, allowing nitrogen uptake to raise the demand for potassium (Silva et al., 2016). Oliveira (2014) pointed out that although there is competition between $\mathrm{NH}_{4}^{+}$and $\mathrm{K}^{+}$because both bind equally to soil particles, this competition is unidirectional, as $\mathrm{K}^{+}$has a negligible effect when compared to the amount of root uptake of $\mathrm{NH}_{4}^{+}$. The effects on potassium contents found at the 150 and $200 \% \mathrm{~N}$ levels are due to the growth stimulation caused by the extra $\mathrm{N}$ supply to the tomato plant, probably causing the dilution phenomenon.

\section{Entomological parameters}

The number of larvae per leaf was lower in N/K ratios that had no nitrogen ( $0 \% \mathrm{~N}$ associated with $0,0.5,100,150$, and $200 \%$ of potassium), where half of the nitrogen was supplied (except 0.5/0.5 and 0.5/2), at the recommended nitrogen dose for the crop $(100 \% \mathrm{~N})$ associated with increasing increases in potassium to the appropriate level $(1 / 0,1 / 0.5$, and $1 / 1)$. The same result was obtained for nitrogen doses at levels $50 \%$ higher than recommended, associated with potassium doses, except at 1.5/0.5, and at the highest nitrogen doses associated with extreme potassium levels (2/0 and $2 / 2$ ) (Table 2$)$. In a condition where adult females of $L$. sativae could not choose another leaf for oviposition other than the one available in the treatments under confinement, it was seen that the lowest amount of larvae mostly occurred in conditions where the nitrogen offered was below $200 \%$ of that indicated for tomato, except in $0.5 / 0.5,0.5 / 2,1 / 1.5,1 / 2,1.5 / 0.5,2 / 0.5,2 / 1$, and $2 / 1.5$.

In this work, lower leaf nitrogen offerings appeared to have stimulated proof-biting of the insects. Once leaf was identified as low-quality food for the offspring, it may be that $L$. sativae females tended to lay fewer eggs and/or once oviposited, the larvae that hatched showed mortality after hatching in some quantity by starvation while still in the leaf mesophyll, while others reached the pupal stage. The result under confinement condition also showed that $L$. sativae showed lower number of larvae per leaf in the ratios where potassium content is equal or higher than nitrogen content, except at $0.5 / 0.5$, $0.5 / 2,1 / 1.5$, and $1 / 2$. It was also found under the conditions of this work that the absence of nitrogen or potassium via tomato nutrition was a conditioning factor for a lower number of larvae per leaf.

The duration of the larval phase (viable larvae) was shorter in treatments where the nitrogen and potassium 
ratio was $0 / 0.5,0 / 1.5,0 / 2,1.5 / 0$, and $1.5 / 2$, indicating that these levels collaborate to the shortening of the life cycle of the leafminer fly, and that there may be an increase in the number of generations throughout the year, which would make the plants more susceptible to its attack. In the absence of nitrogen application, the potassium levels found varied, showing that when viable, there was a greater dependence on $\mathrm{K}$ by the larvae compared to $\mathrm{N}$. At the $1.5 / 0$ and $1.5 / 2$ dose it was found that when the $\mathrm{N}$ dose is $50 \%$ higher than adequate, there is no dependence on $\mathrm{K}$ for the reduction of this phase, but when present, potassium should be higher than nitrogen $(1.5 / 2)$. Thus, in the relationships described, the duration of the larval stage ranged from 3.00 to 3.25 days (Table 2). Under field conditions and conventional cultivation, Fornazier et al. (2010) observed for this same pest a larval phase duration ranging from 6 to 10 days. The nutritional quality of insect food has a direct influence on the duration of the larval stage, since the duration of the biological cycle can be altered according to the quantity and quality of food consumed during this stage (Panizzi \& Parra, 2009). The shorter duration of the larval stage in which the $\mathrm{N} / \mathrm{K}$ ratios had absence of nitrogen and presence of potassium in the pot fertilization suggests that these nutritional conditions, for the leafminer fly adults under confinement, ensure a feeding condition capable of providing essential nutrients for larvae and at the same time provided higher developmental efficiency for this stage. However, it must also be assumed that shorter larval phase lengths may compromise the insect's further development to adult viability, although the phase analyzed reflects that which relates to plant damage. It is worth noting that, although $\mathrm{N}$ was not supplied, the plants showed minimal levels of this nutrient.

The lowest averages found for larval stage duration ranged from 4.5 to 6.5 days and pupal duration from 4.33 to 6.33 days (Table 2). Costa-Lima et al. (2015) reviewing studies on $L$. sativae observed that the duration of the larval phase of this pest ranges from 5 days to 9 days in the pupal phase. The higher averages obtained in $\mathrm{N} / \mathrm{K}$ ratios that had at least the minimum added nitrogen and potassium (50\% below adequate) suggest that the leafminer fly adults under confinement would have the conditions that ensured a minimum feeding condition providing essential nutrients for larvae. Nitrogen plays an important role in several metabolic processes and in genetic encoding, thus interfering with insect growth and fecundity (Panizzi \& Parra, 2009). Potassium, in turn, affects the leafminer fly even more, because it is indispensable to diptera (Chaboussou, 1999) and its demand is considerable to aid growth and development processes, as well as being important for ion balancing and membrane permeability.

The lowest larval viabilities (LV) of the leafminer fly were obtained in the treatments where the ratios between the levels were 0/0,0/100, 100/0, 100/100 (Table 2), indicating

Table 2. Average duration of larval and pupal stages and viability, pupal duration, longevity, and sex ratio of the leafminer fly Liriomyza sativae Blanchard as a function of nitrogen/potassium ratios for tomato (Solanum lycopersicum) fertilization.

\begin{tabular}{|c|c|c|c|c|c|c|c|c|c|c|c|c|c|}
\hline $\begin{array}{l}\mathrm{N} / \mathrm{K} \\
\text { ratios }\end{array}$ & $\begin{array}{l}\text { Larva } \\
\text { per leaf } \\
\text { (units) }\end{array}$ & $\begin{array}{c}\mathrm{N} / \mathrm{K} \\
\text { ratios }\end{array}$ & $\begin{array}{l}\text { Larval } \\
\text { viability } \\
(\%)\end{array}$ & $\begin{array}{l}\mathrm{N} / \mathrm{K} \\
\text { ratios }\end{array}$ & $\begin{array}{c}\text { Duration } \\
\text { of larval } \\
\text { phase } \\
\text { (days) } \\
\end{array}$ & $\begin{array}{l}\mathrm{N} / \mathrm{K} \\
\text { ratios }\end{array}$ & $\begin{array}{c}\text { Pupal } \\
\text { viability } \\
(\%)\end{array}$ & $\begin{array}{c}\mathrm{N} / \mathrm{K} \\
\text { ratios }\end{array}$ & $\begin{array}{l}\text { Duration } \\
\text { of pupal } \\
\text { phase } \\
\text { (days) }\end{array}$ & $\begin{array}{l}\mathrm{N} / \mathrm{K} \\
\text { ratios }\end{array}$ & $\begin{array}{l}\text { Longevity } \\
\text { (days) }\end{array}$ & $\begin{array}{l}\mathrm{N} / \mathrm{K} \\
\text { ratios }\end{array}$ & $\begin{array}{l}\text { Sexual } \\
\text { reason }\end{array}$ \\
\hline $2 / 0$ & - & $2 / 0$ & - & $0 / 0$ & - & $2 / 0$ & - & $0 / 0.5$ & 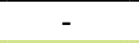 & $1 / 1$ & - & $0 / 0$ & - \\
\hline $0.5 / 0$ & - & $0.5 / 0$ & - & $1 / 1$ & - & $0 / 0$ & - & $0 / 0$ & - & $0 / 0$ & - & $1 / 1$ & - \\
\hline $0 / 1$ & $1.33 b$ & 0/1 & $0.00 \mathrm{c}$ & $2 / 0$ & - & $0 / 1$ & - & $0 / 1$ & - & $1 / 0$ & - & $0 / 1$ & - \\
\hline $0 / 0$ & $1.66 \mathrm{~b}$ & $1 / 0$ & $00 \mathrm{c}$ & $0.5 / 0$ & - & $1 / 1$ & - & $1 / 0$ & - & $0 / 1$ & - & $1 / 0$ & - \\
\hline $1 / 1$ & $2.66 \mathrm{~b}$ & $0 / 0$ & ת & 0/1 & - & $0.5 / 0$ & - & $1 / 1$ & - & $0.5 / 0$ & - & $2 / 0$ & - \\
\hline $1.5 / 2$ & $3.00 \mathrm{~b}$ & $1 / 1$ & $0.00 c$ & $1 / 0$ & - & $1 / 0$ & - & $0.5 / 0$ & - & $2 / 0$ & - & $0.5 / 0$ & - \\
\hline $1.5 / 0$ & $4.00 \mathrm{~b}$ & $0 / 0.5$ & $44.24 b$ & $1.5 / 0$ & $3.00 \mathrm{~b}$ & 0/1.5 & $33.33 b$ & $2 / 0$ & - & $0 / 0.5$ & - & $0 / 0.5$ & - \\
\hline 0/0.5 & $5.33 b$ & $1.5 / 1$ & $45.83 \mathrm{~b}$ & $0 / 1.5$ & $3.00 \mathrm{~b}$ & $0 / 2$ & $.50 \mathrm{~b}$ & $1.5 / 2$ & $4.33 a$ & $1 / 2.0$ & $1.00 \mathrm{~d}$ & $1.5 / 2$ & $0.30 \mathrm{~b}$ \\
\hline $1 / 0.5$ & $5.66 \mathrm{~b}$ & $0 / 2$ & $47.77 b$ & $0 / 0.5$ & $3.00 \mathrm{~b}$ & $0 / 0.5$ & $1.16 \mathrm{a}$ & $0.5 / 0.5$ & $6 \mathrm{a}$ & $1.5 / 0.5$ & & $2 / 1.5$ & $0.30 \mathrm{~b}$ \\
\hline $1.5 / 1$ & $6.00 \mathrm{~b}$ & $1.5 / 0$ & $57.57 a$ & $1.5 / 2$ & & $1.5 / 2$ & & $2 / 1.5$ & & $1 / 1.5$ & & $0 / 2$ & $0.33 b$ \\
\hline $2 / 2$ & $6.00 \mathrm{~b}$ & $0 / 1.5$ & $58.62 \mathrm{a}$ & $0 / 2$ & $3.25 b$ & $2 / 1$ & $61.32 \mathrm{a}$ & $1.5 / 1$ & $5.33 \mathrm{a}$ & $1.5 / 1$ & $2.00 \mathrm{c}$ & $1.5 / 1$ & $0.33 b$ \\
\hline $1 / 0$ & $7.00 \mathrm{~b}$ & $1.5 / 2$ & $60.00 \mathrm{a}$ & $0.5 / 1.5$ & $4.50 \mathrm{a}$ & $0.5 / 0.5$ & $61.32 \mathrm{a}$ & $2 / 1$ & $5.33 \mathrm{a}$ & $1.5 / 2$ & $2.00 \mathrm{c}$ & $1.5 / 0$ & $0.37 b$ \\
\hline $0 / 2$ & $7.00 \mathrm{~b}$ & $1.5 / 1.5$ & 81.48 a & $1 / 0.5$ & & $1.5 / 0$ & $66 \mathrm{a}$ & $0.5 / 1.5$ & & $0 / 2$ & & $1 / 1.5$ & $0.37 b$ \\
\hline $0.5 / 1$ & $10.66 \mathrm{~b}$ & $0.5 / 0.5$ & $92.92 \mathrm{a}$ & $2 / 1.5$ & $.00 \mathrm{a}$ & $1 / 0.5$ & $70.47 a$ & $0 / 2$ & $5.51 \mathrm{a}$ & $0 / 1.5$ & $.00 \mathrm{c}$ & $0.5 / 1.5$ & $0.38 b$ \\
\hline $0.5 / 1.5$ & $.00 \mathrm{~b}$ & $0.5 / 2$ & $94.21 \mathrm{a}$ & $0.5 / 0.5$ & $5.00 \mathrm{a}$ & $2 / 2$ & 77.77 a & $0 / 1.5$ & $5.51 \mathrm{a}$ & $0.5 / 0.5$ & $2.00 \mathrm{c}$ & $1 / 2.0$ & $0.40 \mathrm{~b}$ \\
\hline $0 / 1.5$ & $11.00 \mathrm{~b}$ & $2 / 1.5$ & $94.44 \mathrm{a}$ & $0.5 / 1$ & $5.00 \mathrm{a}$ & $1.5 / 0.5$ & $78.31 \mathrm{a}$ & $2 / 0.5$ & $5.66 \mathrm{a}$ & $0.5 / 1$ & $2.00 c$ & $0.5 / 1$ & $0.42 b$ \\
\hline $1.5 / 1.5$ & $13.33 b$ & $0.5 / 1$ & $95.00 \mathrm{a}$ & $1.5 / 1$ & $5.00 \mathrm{a}$ & $0.5 / 1$ & $78.82 \mathrm{a}$ & $0.5 / 1$ & $5.66 \mathrm{a}$ & $0.5 / 2$ & $2.33 c$ & $0 / 1.5$ & $0.46 b$ \\
\hline $0.5 / 0.5$ & $19.33 \mathrm{a}$ & $2 / 1$ & $99.25 \mathrm{a}$ & $2 / 1$ & & $1 / 1.5$ & & $1 / 2.0$ & & $0.5 / 1.5$ & $2.33 c$ & $1 / 0.5$ & $0.50 \mathrm{a}$ \\
\hline 2/1.5 & $19.66 \mathrm{a}$ & $2 / 0.5$ & $100.00 \mathrm{a}$ & $2 / 2$ & & $1.5 / 1.5$ & $87.08 \mathrm{a}$ & $2 / 2$ & & $1.5 / 1.5$ & & $1.5 / 0.5$ & $0.50 \mathrm{a}$ \\
\hline $1 / 2$ & $19.66 \mathrm{a}$ & $2 / 2$ & a & $2 / 0.5$ & & $1.5 / 1$ & & $1.5 / 0$ & & $1 / 0.5$ & & $2 / 2$ & $0.50 \mathrm{a}$ \\
\hline $1 / 1.5$ & $24.00 \mathrm{a}$ & $0.5 / 1.5$ & $0.00 \mathrm{a}$ & $1.5 / 0.5$ & $6.50 \mathrm{a}$ & $0.5 / 1.5$ & $90.47 a$ & $1.5 / 1.5$ & $0 \mathrm{a}$ & $1.5 / 0$ & $3.00 \mathrm{~b}$ & $2 / 1$ & $0.55 \mathrm{a}$ \\
\hline $0.5 / 2$ & $26.33 \mathrm{a}$ & $1.5 / 0.5$ & $100.00 \mathrm{a}$ & $1.5 / 1.5$ & $6.50 \mathrm{a}$ & $0.5 / 2$ & $92.60 \mathrm{a}$ & $1 / 0.5$ & $6.00 \mathrm{a}$ & $2 / 0.5$ & $4.33 a$ & $2 / 0.5$ & $0.59 a$ \\
\hline $1.5 / 0.5$ & 31.00 a & $1 / 0.5$ & $100.00 \mathrm{a}$ & $0.5 / 2$ & $6.50 \mathrm{a}$ & $2 / 0.5$ & $93.73 \mathrm{a}$ & $1 / 1.5$ & $6.00 \mathrm{a}$ & $2 / 2$ & 4.66 a & $0.5 / 2$ & $0.60 \mathrm{a}$ \\
\hline $2 / 1$ & & $1 / 2$ & $100.00 a$ & $1 / 2$ & $6.50 \mathrm{a}$ & $1 / 2$ & $100.00 \mathrm{a}$ & $1.5 / 0.5$ & $6.33 a$ & $2 / 1$ & $5.00 \mathrm{a}$ & $1.5 / 1.5$ & $0.60 \mathrm{a}$ \\
\hline $2 / 0.5$ & $36.66 \mathrm{a}$ & $1 / 1.5$ & $100.00 \mathrm{a}$ & $1 / 1.5$ & $6.50 \mathrm{a}$ & $2 / 1.5$ & $100.00 \mathrm{a}$ & $0.5 / 2$ & $6.33 \mathrm{a}$ & $2 / 1.5$ & $5.00 \mathrm{a}$ & $0.5 / 0.5$ & $0.66 \mathrm{a}$ \\
\hline
\end{tabular}

${ }^{*}$ Averages followed by the same letter in the column do not differ at $5 \%$ by the Scott-Knott test. 
that, under controlled conditions in the greenhouse, these levels provided the tomato plant with a condition in which the plant made it impossible and/or reduced the feeding efficiency of $L$. sativae, since it did not allow the pest to advance in its life cycle, not causing damage to the crop. On the other hand, it is important to point out that only the 1/1 level is agronomically indicated for the crop. Thus, within the limits established for the experimental conditions of the confinement, it can be assumed, based on the results obtained, that there are indications that the pest $L$. sativae presents lower infestation in the plant provided by the balanced use of nitrogen and potassium fertilization (1/1) recommended for tomato cultivation in the state of Espírito Santo. This finding is supported by Chaboussou (1999) through the trophobiosis theory, which states that the insects' food satisfaction will only occur when the plant it intends to feed on is in the biochemical state corresponding to its trophic requirements. This requirement, mostly formed by the presence of free amino acids, sugars, and nitrates can be found in nutritionally unbalanced plants (Santos \& Silva, 2020).

The viability of the larval stage represents one of the most important factors for population growth (Oliveira, 2014), since as larval viability decreases, the increase in the insect population is disadvantaged. There are several factors that corroborate this result. Nitrogen is important for the synthesis of amino acids and proteins, which are the limiting substances for insect survival. As its supply is inadequate to the tomato plant (levels 0 and $50 \%$ ), which in turn was the food source for the leaf fly larvae, the production of amino acids and proteins in the leaf tissue is compromised. Already at the adequate level $(100 \%)$, the appearance of free amino acids produced in the leaves is almost nil, which allows for increased plant resistance (Chaboussou, 1999).

As for K levels, Becker et al. (2016) pondered that in plants grown without added potassium, there may be chemical changes inside the cell, such as accumulation of soluble nitrogen compounds. However, this may not have been observed because the nitrogen levels associated with the absence of potassium were insufficient to provide increased larval viability ( $\mathrm{N} / \mathrm{K} 0 / 0 ; \mathrm{N} / \mathrm{K} 0.5 / 0)$. However, at $\mathrm{N} / \mathrm{K} 1 / 0$ and $\mathrm{N} / \mathrm{K} 2 / 0$ although the $\mathrm{N}$ level is adequate or higher, it was not able to provide the necessary conditions for larval development. This may be related to the fact that although there was sufficient $\mathrm{N}$ availability for the leaf supply of amino acids and proteins, the absence of potassium made the leaf tissue unsuitable for feeding $L$. sativae, probably because potassium is essential to the diptera (Chaboussou, 1999). As for the adequate level for nitrogen and potassium ( $N / K$ ratio $1 / 1$ ), it can be observed that a $100 \% \mathrm{~K}$ input is necessary for the amino acids to be adequately utilized by the plants in protein synthesis (Chaboussou, 1999). However, it is worth noting that among the ratios that showed the greatest potential in inducing resistance to $L$. sativae, only the $N / K 1 / 1$ ratio contemplates what it was proposed by Liebig through the Law of the Minimum, indicating that in the use of $100 \%$ adequate levels of nitrogen and potassium there was no limiting nutrient for tomato plant production (Pereira et al., 2019).

Analyses of the relationships between nitrogen and potassium on tomato leafminer fly resistance discussed for the larval viability parameter also allows to verify their effects on susceptibility, because as resistance decreases, susceptibility increases (Oliveira, 2014). The parameters that obtained different averages from those where the plants manifested induced resistance indicate $\mathrm{N} / \mathrm{K}$ ratios more favorable to the pest, i.e., those where the plants became more susceptible.

The duration of the pupal phase (DFP) showed no statistical difference between the means obtained, indicating that the different levels of nitrogen and potassium were not able to influence this parameter between the treatments. However, it was possible to verify that at the $\mathrm{N} / \mathrm{K}$ ratios that had at least the minimal addition of nitrogen and/or potassium, except at $N / K 1 / 1$, it was possible to determine the duration of the pupal phase (Table 2).

Pupal viability (PV) was highest at $\mathrm{N} / \mathrm{K}$ ratios $0 / 0.5,1.5 / 2$, $2 / 1,0.5 / 0.5,1.5 / 0,1 / 0.5,2 / 2,1.5 / 0.5,0.5 / 1,1 / 1.5,1.5 / 1.5$, $1.5 / 1,0.5 / 1.5,0.5 / 2,2 / 0.5,1 / 2$, and $2 / 1.5$ (Table 2). Note that the observed nitrogen and potassium ratios showed at least minimal addition of these nutrients, except for the $\mathrm{N} / \mathrm{K}$ $0 / 0.5$ and $N / K$ 1.5/0 ratios. The need for a minimum amount of nitrogen and potassium to obtain the highest averages observed shows that the nutrients $\mathrm{N}$ and $\mathrm{K}$ are essential for PV, showing that the absence of these nutrients favors pupal mortality, thus indicating the occurrence of nutritional inadequacies for the leafminer fly because $\mathrm{N}$ and $\mathrm{K}$ are associated with the production of soluble amino acids, which is the main source of food for L. sativae.

For the longevity parameter (LG) (days), it is noted that the highest averages obtained were between 4.33 and 5.00 days and observed in the treatments where there was the maximum addition of nitrogen associated with the use of potassium (Table 2). The differences obtained in longevity may be associated with the individual's own characteristics or with its ability to convert the food assimilated during the larval stage, generating consequences in the longevity of adults. Panizzi \& Parra (2009) stated that many aspects of insect biology, including their behavior and physiology, are in one way or another related to the nutritional state of plants, a fact that could justify the increase in longevity as nitrogen doses increased in tomato cultivation.

The highest means obtained for the sex ratio parameter were found in ratios where the number of males is similar to the number of females $(1: 1)$ in the NK $1 / 0.5$, NK 1.5/0.5, and NK $2 / 2$ ratios and in ratios where the number of females were higher than males obtained in the $\mathrm{N} / \mathrm{K} 0.5 / 0.5, \mathrm{NK} 0.5 / 2$, NK1.5/1.5, NK 2/0.5, and NK 2/1 ratios (Table 2). From what it was observed, it can be assumed that the nitrogen and potassium contents in the proportions in which they were offered to the tomato plants do not have a relationship that directly influences the ratio of males to females of $L$. sativae. The results obtained are similar to those verified by Parrela (1987), who considers that the sex ratio of Liriomyza sp. observed according to the genus pattern is 1:1. 


\section{Conclusions}

The application of increasing levels of $\mathrm{K}$, associated with increasing levels of $\mathrm{N}$, favored the absorption of $\mathrm{N}$, providing higher leaf contents of this nutrient; however, this effect was not observed for leaf $\mathrm{K}$ contents.

The $N / K 1 / 1$ ratio showed unfavorable averages for the insect among the parameters evaluated (average duration of larval and pupal stages and viability, duration of pupal stage, longevity, and sex ratio), indicating a possible induced resistance of tomato to the leafminer fly under confinement condition.

Tomato plants showed at the $\mathrm{N} / \mathrm{K}$ ratio $1 / 0,0 / 0,0 / 1$, $2 / 0$, and $0.5 / 0$ some inhibitory effect on egg viability and/or feeding of $L$. sativae larvae.

The different ratios of the $1 / 1 \mathrm{~N} / \mathrm{K}$ ratio used in tomato fertilization where the leafminer flies were confined (except for $\mathrm{N} / \mathrm{K} 1 / 0,0 / 0,0 / 1,2 / 0$, and $0.5 / 0$ ) made the plants more susceptible to oviposition and feeding by the insects.

\section{Compliance with Ethical Standards}

Author contributions: Conceptualization: CMRO, RRP, DP; Data curation: CMRO,RRP,DP; Formal analysis: RRP, DP, AMH, OJPR; Acquisition of financing: RRP, DP; Investigation: CMRP, RRP, DP; Methodology: CMRO, RRP, DP; Project administration: CMRO; Resources: RRP, DP; Supervision: RRP, DP; Validation: RRP, DP, AMH, OJPR; View: CMRO, RRP; Writing - original draft: CMRO; Writing - proofreading and editing: CMRO, RRP, DP.

Conflict of interest: The authors declare that there are no conflicts of interest.

Financing source: Coordenação de Aperfeiçoamento de Pessoal de Nível Superior (CAPES) and Conselho Nacional de Desenvolvimento Científico e Tecnológico (CNPq).

\section{Literature Cited}

Becker. W.F.; Wamser, A.F.; Feltrim, A.L.; Suzuki, A.; Santos, J.P.; Valmorbida, J.; Hahn, L.; Marcuzzo, L.L; Mueller, S. Sistema de produção integrada para o tomate tutorado em Santa Catarina. Florianópolis: Epagri, 2016. 149p. https://ifc.edu.br/wpcontent/uploads/2017/05/web-miolo-epagri-Gr\%C3\%A1fica\%C3\%9Altima-vers\%C3\%A3o.pdf. 14 Jul. 2020.

Butzke, A.G. Produção de mudas de açaízeiro solteiro (Euterpe precatoria Mart.) sob diferentes doses de nitrogênio e potássio. Rio Branco: Universidade Federal do Acre, 2019. 74p. PhD Thesis. https://www. alice.cnptia.embrapa.br/handle/doc/1114744. 28 Jul. 2020.

Centro de Estudos Avançados em Economia Aplicada - Cepea. Anuário 2019-2020. Hortifruti Brasil. n.196, p.1-52, 2019/2020. https://www. hfbrasil.org.br/br/revista/acessar/completo/anuario-2019-2020retrospectiva-2019-perspectivas-2020-dos-hf-s.aspx. 06 Sep. 2020.

Chaboussou, F. Plantas doentes pelo uso de agrotóxicos: a teoria da trofobiose. 2.ed. Porto Alegre: L \& PM, 1999. 256 p.

Costa-Lima, T.C. da; Geremias, L.D.; Begiato, A.M.; Chagas, M.C.M. Das; Parra, J.R.P. Sistema de criação de parasitoide de moscaminadora. Petrolina: Embrapa Semiárido, 2017. 8p. https://www. infoteca.cnptia.embrapa.br/infoteca/bitstream/doc/1078329/1/ CTE116.pdf. 02 Aug. 2020.
Costa-Lima, T.C.; Chagas, M.C.M; Parra, J.R.P. Comparing potential as biocontrol agents of two neotropical parasitoids of Liriomyza sativae. Neotropical Entomology, v. 48, p. 660-667, 2019. https:// doi.org/10.1007/s13744-018-00667-0.

Costa-Lima; T.C.; Silva, A. C.; Parra, J.R.P. Moscas-minadoras do gênero Liriomyza (Diptera: Agromyzidae): aspectos taxonômicos e biologia. Petrolina: Embrapa Semiárido, 2015. 36p. https://www. infoteca.cnptia.embrapa.br/infoteca/bitstream/doc/1078329/1/ CTE116.pdf. 28 Sep. 2020.

Félix, A.C.C.; Silva,F. de A.C. da; Guedes, I.M.R.; Lima, C.E.P.; Silva, J. da. Acúmulo e exportação de nutrientes pelo tomateiro BRS Nagai. In: Congresso Brasileiro de Ciência do Solo, 35., 2015, Natal. Anais... Natal: SBCS; Embrapa Solos, 2015. 4p. https://ainfo. cnptia.embrapa.br/digital/bitstream/item/134418/1/CongressoBrasileiro-de-Ciencia-de-Solo-Resumo-Juscimar.pdf. 22 Jun. 2020.

Ferreira, D.F. Sisvar: A computer analysis system to fixed effects split plot type designs. Revista Brasileira de Biometria, v. 37, n. 4, p. 529-535, 2019. http://www.biometria.ufla.br/index.php/BBJ/ article/view/450. 14 Jul. 2020.

Fornazier, J.M.; Pratissoli, D.; Martins, D. dos. S. Principais pragas da cultura do tomateiro estaqueado na região das montanhas do Espírito Santo. In. Instituto Capixaba de Pesquisa, Assistência Técnica e Extensão Rural (Ed.). Tomate. Vitória: Incaper, 2010, p. 185-226.

Freire, J. C.; Ribeiro, M. A.V.; Bahia, V.G.; Lopes, A. S.; Aquino, L.H. Resposta do milho em casa de vegetação a níveis de água em solos da região de Lavras-MG. Revista Brasileira de Ciência do Solo, v. 4, n. 1, p. 5-8, 1980. https://www.infoteca.cnptia.embrapa.br/ infoteca/bitstream/doc/1078329/1/CTE116.pdf. 22 Jun. 2020.

Instituto Capixaba de Pesquisa, Assistência Técnica e Extensão Rural Incaper. Monitoramento agroclimático - Alegre/ES. 2020. https:// meteorologia.incaper.es.gov.br/monitoramento-alegre. $14 \mathrm{Jul}$. 2020.

Novais, R. F.; Neves, J.C.L.; Barros, N.F. Ensaio em ambiente controlado. In: Oliveira, A.J.; Garrido, W. E.; Araújo, J.D.; Lourenço, S. (Orgs.). Métodos de pesquisa em fertilidade do solo. Brasília: Embrapa; SEA, 1991. p. 189-255.

Oliveira, C. M. R. Relações entre fertilidade do solo, nutrição mineral do tomateiro (Solanum lycopersicum) e seu efeito sobre a mosca-minadora Liriomyza sativae (Blanchard, 1938) (Diptera: Agromyzidae). Universidade Federal do Espírito Santo: Alegre, 2014. 108 p. PhD Thesis. http://repositorio.ufes.br/ handle/10/4881. 22 Jun. 2020.

Panizzi, A., Parra, J.R.P. Bioecologia e nutrição de insetos como base para o manejo integrado de pragas. In. Panizzi, A., Parra, J.R.P. (Eds.). Bioecologia e nutrição de inseto: base para o manejo integrado de pragas. 2.ed. Brasília: Embrapa, 2009, p. 1107-1139.

Pereira, E.G.; Dias, A.C.; Silva, C.S.R.A.; Gomes, L.B.E.; Almeida, L.C.H.; Ferreira, N.S.; Santos, O.A.Q.; Moura, O.V.T.; Bucher, C.P.C.; Bucher, C.A.; Zonta, E.; Fernandes, M.S. Deficiência de cálcio e magnésio afeta o metabolismo de nitrogênio e o desenvolvimento de plantas de arroz (Oryza sativa L.). In. Silva, A. S. (Org.). Agronomia: elo da cadeia produtiva. Ponta Grossa: Atena Editora, 2019. 30 p. 
Pinto, L.E.V.; Araújo, F.F. Uso de vinhaça como biofertilizante: efeito na nodulação, crescimento e acúmulo de nutrientes no cultivo da soja. Colloquium Agrariae, v. 15, n.5, p. 97-109, 2019. https:// revistas.unoeste.br/index.php/ca/article/view/3054. 15 Jul. 2020.

Prezotti, L.C. Gomes, J.A.; Dadalto, G.G.; Oliveira, J.A. Manual de recomendação de calagem e adubação para o estado do Espírito Santo. 5a aproximação. Vitória: SEEA; INCAPER; CEDAGRO, 2007. $301 \mathrm{p}$.
Santos, R.R.O.; Silva, Q.P.S. A Importância da trofobiose para a saúde das plantas: fundamentos para a produção orgânica. Revista Opara: Ciências Contemporâneas Aplicadas, FACAPE, v. 10, n. 1, p. 2-13, 2020. http://codeagro.agricultura.sp.gov.br/uploads/ capacitacao/TROFOBIOSE.pdf. 14 Jul. 2020.

Silva, J.T.A.; Silva, I.P.; Simão, F.R. Produção e nutrição de limoeiro 'Tahiti' em função da adubação com nitrogênio e potássio em cinco safras. Pesquisa Agropecuária Brasileira, v.51, n.4, p.357363, 2016. https://doi.org/10.1590/S0100-204X2016000400008. Teixeira, P.C.; Donagemma, G.K.; Fontana, A.; Teixeira, W.G. Manual de métodos de análise de solo. 3.ed. Brasília: Embrapa, 2017. 574p. 